Acta vet. scand. $1978,19,520-534$.

From the Finnish Fur Breeders' Association, Feed Laboratory, Vaasa, Finland.

\title{
BACTERIOLOGICAL QUALITY OF READY-MIXED MINK FEED IN FINLAND
}

\author{
By \\ Tapio Juokslahti
}

\begin{abstract}
JUOKSLAHTI, T.: Bacteriological quality of ready-mixed mink feed in Finland. Acta vet. scand. 1978, 19, 520-534. - Frozen samples of Finnish ready-mixed mink feed were analyzed for total bacterial count, the number of faecal streptococci, the coliform count, the number of haemolytic bacteria and the number of sulphite-reducing bacteria. The investigation comprised 242 feed samples from 38 central kitchens and larger private farm kitchens, the combined feed production of which is about $85 \%$ of the yearly feed production of Finland. Of all samples $48.3 \%$ had a total bacterial count of $10^{6} \ldots 6 \times 10^{6}$ bacteria per $\mathrm{g}$ of feed. The total bacterial count was relatively constant during the first four production periods of the year (DecemberAugust) and was elevated during the last period (September-November). The percentage of samples containing less than $2.5 \times 10^{4}$ faecal streptococci per $\mathrm{g}$ of feed was $49.8 \% ; 62 \%$ of the samples contained less than $2.5 \times 10^{4}$ coliform bacteria per g. The content of coliform bacteria was lowest during the third production period (May); $48.5 \%$ of the samples contained $5 \times 10^{3} \ldots 10^{5}$ haemolytic bacteria per $\mathrm{g}$, and $4.6 \%$ were negative. The content of haemolytic bacteria was relatively constant during the whole production year; $52.6 \%$ of the feed samples contained $5 \times 10^{3} \ldots 10^{5}$ sulphite-reducing bacteria per g, and $17.2 \%$ were negative. The mean content of sulphite-reducing bacteria was lowest during the second production period (MarchApril).

The results are discussed and compared with corresponding results from Norway and Denmark.
\end{abstract}

mink feed quality; bacteria in mink feed.

In the production of ready-mixed mink feed various by-products of the food industry are used. The total production of ready-mixed mink feed and the raw materials used in Finland in 1976 are shown in Table 1 (Finnish Fur Breeders' Association's statistics 1977). Some $80-85 \%$ of the ready-mixed feed is produced in central kitchens, of which there were 39 at the end of 1976. Before being processed into mink feed, part of the raw materials is stored in refrigerated or dry store-rooms or is 
T a ble 1. Total production of ready-mixed mink feed and the raw materials used in 1976 in Finland (Finnish Fur Breeders' Association's statistics 1977).

\begin{tabular}{lr}
\hline Raw material & Quantity kg \\
\hline Slaughter-house offals & 46000000 \\
Mink carcasses & 3000000 \\
Baltic herring & 32000000 \\
Mintaj fish & 18000000 \\
Cod filetting offal & 50000000 \\
Fish-meal & 7000000 \\
Meatbone meal & 1500000 \\
Wheat germ & 2000000 \\
Brewers yeast & 1200000 \\
Vitamin mixture & 4000000 \\
Cereals & 29000000 \\
Others (milk, potatoes, soya meal etc.) & 6000000 \\
Water & 69000000 \\
\hline Total production & 269000000 \\
\hline
\end{tabular}

preserved chemically, part of it is used immediately in feed production. The feed is made out of the raw materials by grinding and mixing into a paste-like mass, in which the moisture content is about $70 \%$ (Kangas 1977). The temperature of the feed after mixing is generally between 0 and $10^{\circ} \mathrm{C}$. The feed is not subjected to heat treatment after this process. The bacteriological quality of the ready-mixed feed thus depends on the bacteriological quality of the raw materials and on possible changes during processing. The feed is distributed to mink farms in insulated bulk cars, and many farms have insulated farm silos in which the feed is kept until it is fed to the animals.

The production-year for minks can be divided into five production periods, taking into account the availability of different feed components and the productive phase of the animals. The chemical composition of the ready-mixed mink feed during various production periods is shown in Table 2 (Analysis results from Feed Laboratory).

P e ri o d I (December-February): During the winter months only those minks are at the farms that are to be used in breeding. For breeding purposes only the best individuals, judged by various qualitative criteria, have been chosen. During this period the breeding stock is fed restrictively, and animals showing signs 
T a b le 2. Chemical composition of ready-mixed mink feed during various production periods (Analysis results from Feed Laboratory).

For production periods, see legend of Fig. 1.

\begin{tabular}{lccccc}
\hline Period & I & II & III & IV & V \\
\hline Dry matter (\%) & $30.6 \pm 2.8^{*}$ & $29.3 \pm 2.2$ & $29.7 \pm 1.5$ & $30.8 \pm 1.5$ & $32.5 \pm 4.5$ \\
In dry matter (\%): & & & & & \\
Ashes & $10.8 \pm 1.8$ & $13.0 \pm 2.1$ & $14.3 \pm 2.1$ & $11.7 \pm 1.1$ & $10.7 \pm 2.4$ \\
Crude protein & $42.9 \pm 6.0$ & $46.5 \pm 3.6$ & $46.8 \pm 3.3$ & $45.7 \pm 3.2$ & $42.6 \pm 3.6$ \\
Crude fat & $17.3 \pm 4.6$ & $14.0 \pm 3.2$ & $14.1 \pm 2.9$ & $15.9 \pm 2.9$ & $17.1 \pm 3.6$ \\
Crude carbohydrates & $29.0 \pm 5.3$ & $26.5 \pm 3.7$ & $24.8 \pm 4.2$ & $26.7 \pm 3.9$ & $29.6 \pm 5.2$ \\
Number of samples & 72 & 61 & 30 & 155 & 109 \\
\hline
\end{tabular}

- mean $\pm \mathrm{s}$

of clinical illness or weakness are eliminated. The chemical composition of the feed during the beginning of this period resembles the autumn feed e.g. having higher content of fat and carbohydrates. During the latter part of this period the feed will have a composition more like that of the breeding season, e.g. higher content of protein. The aim is to maintain the hygienic quality of the feed at as high a level as possible, because of the coming breeding season. The feed producers are advised to use only good-quality slaughter-house offals during the latter part of this period (Juokslahti 1977 a).

P e riod I I (March-April): In the first week of March the breeding season begins and lasts until the end of the month. It is followed by the pregnancy period, which ends in the whelping season (April-May). During the second period the feed is composed so as to give large protein quantity to the pregnant females. During this period also the best quality raw materials are used for feed production.

P e riod II I (May): After whelping the nursing season begins ending by the middle of June. During this period the nursing females require a feed rich in energy, e.g. fat, for the milk production. This is achieved by using high quantities of fat containing Baltic herring in the feed. During this period most of the deep-freezing capacity of the central kitchens is needed for the freezing and storing of the spring-spawing Baltic herring, which is now available in large quantities. Thus the slaughterhouse offal, which during the previous periods would mostly have been frozen on arrival, must now be used without freezing. 
P e riod I V (June-August): During this period the mink whelps begin to eat solid feed and their body weight increases rapidly. Feed production in the central kitchens increases rapidly during this period, so that between June and August about $36 \%$ of the total yearly output is produced (Kangas). The rapidly growing whelps now need a feed of good hygienic quality, but because of the greatly stepped-up production raw materials of inferior quality must in part be used. The relatively warm weather of the summer months makes good hygiene in the feed production process even more important. During this period the animals should be given adequate quantities of protein and energy to ensure normal body weight development (Kangas).

P e ri o d V (September-November): During this period the minks develop their winter fur, and when this process is completed in November they are pelted. Pelt development requires sufficient amount of protein to be normally completed (Kangas). During this period, however, there is a tendency for higher contents of fat and carbohydrates in the feed. Before the pelting season, raw materials of lower quality are used up. In December, feed production is down to only $3 \%$ of the total yearly production (Kangas).

Because of its composition, the ready-mixed mink feed is sensitive to bacteriological spoilage and may also contain pathogenic bacteria derived from the raw materials. Of the Scandinavian countries, Norway and Denmark have established systematic bacteriological quality control of ready-mixed mink feed (Loftsgård \& Yndestad 1970, 1973, Hansen 1973). According to the literature, only a few bacteriological analyses of ready-mixed mink feed have been performed in Sweden and Finland (Mejerland 1975, Kangas). The purpose of this study was to evaluate the bacteriological status of ready-mixed mink feed in Finland, by bacteriological analysis of feed lots from different central kitchens during various periods of the annual production cycle.

\section{MATERIALS AND METHODS}

The investigation comprised 242 feed samples that were delivered to the feed laboratory of the Finnish Fur Breeders' Assosiation between September 1976 and August 1977. The samples originated from 38 central kitchens and larger private farm kitchens, the combined yearly production of which is about $85 \%$ 
of the total production of ready-mixed mink feed in Finland. The samples were collected immediately after the mixing procedure from different feed batches, so that the sample delivered for analysis represented the total feed production of one day. The sample (total weight about $1 \mathrm{~kg}$ ) was packed in plastic bags and kept at a temperature of approx. $-18^{\circ} \mathrm{C}$ until the following day, when it was packed in an insulated styrox container and sent to the laboratory. In some cases the sample sent to the laboratory represented three days' feed production.

In the laboratory the sample was partially thawed and thoroughly mixed by hand. A 2-g sample of the mixture was then taken for bacteriological analysis. The sample was homogenized $2 \mathrm{~min}$. in $20 \mathrm{ml}$ sterile isotonic saline with an Ultra Turrax homogenizer (Janke \& Kunkel, Stauffen, Germany).

Throughout the investigation common methods of bacteriological analysis were used. All the substrates used were from Orion Diagnostica ${ }^{*}$. The total bacterial count was determined on nutrient agar; the incubation time was $48 \mathrm{hrs}$. and the temperature $30^{\circ} \mathrm{C}$. The number of faecal streptococci was determined on Slanetz and Bartley agar (Slanetz \& Bartley 1957) with an incubation time of $18-24 \mathrm{hrs}$. and a temperature of $37^{\circ} \mathrm{C}$. The coliform count was determined using VRB-agar (violet red bile); the incubation time was again $18-24 \mathrm{hrs}$. and the temperature $37^{\circ} \mathrm{C}$. In all the analyses the appropriate dilution of the sample was mixed with the melted substrate in petri dishes. The number of haemolytic bacteria was determined from a surface spread on nutrient agar containing $7 \%$ of defibrinated bovine blood. The incubation time was $18-24 \mathrm{hrs}$. and the incubation temperature $37^{\circ} \mathrm{C}$. Only those colonies which were surrounded by a clear haemolytic zone were counted. The number of the sulphitereducing bacteria was determined in test tubes, $\varnothing 10 \mathrm{~mm}$, containing $8 \mathrm{ml}$ iron sulphite agar (Mossell et al. 1956). The incubation time was $48 \mathrm{hrs}$. and the temperature $37^{\circ} \mathrm{C}$. The monthly distribution of the number of samples is shown in Table 3.

In order to test the reproducibility of the bacteriological results, duplicate samples (labelled A and B), both representing the same day's feed production of a central kitchen and taken and sent to the laboratory as described above, were obtained from seven central kitchens. After the microbiological analyses,

* Orion Diagnostica, Espoo, Finland. 
T a b le 3. Monthly distribution of samples for bacteriological analyses of ready-mixed mink feed. Each sample is a mixture of the different batches of either one day's or three days' production of a central kitchen.

\begin{tabular}{lc}
\hline Month & Number of samples \\
\hline December, January & 10 \\
February & 22 \\
March & 16 \\
April & 30 \\
May & 23 \\
June & 25 \\
July & 30 \\
August & 22 \\
September & 28 \\
October & 22 \\
November & 14 \\
\hline Total & 242 \\
\hline
\end{tabular}

the difference between the logarithmic values of the corresponding bacterial counts of samples A and B was tested statistically and the correlation coefficients between the values determined (Fisher 1958).

\section{RESULTS}

The mean differences in the logarithmic values of the various bacterial counts of samples $A$ and $B$ from the seven central kitchens were in no instance found to be statistically significant. The mean differences (mean $\pm s$ ) of the logarithmic values and the correlation coefficients $(r)$ between the results for samples $A$ and $B$ were: $0.138 \pm 0.482, r=0.78$ for total bacterial counts, $0.194 \pm 0.285, \mathrm{r}=0.90$ for haemolytic bacteria, $0.420 \pm 0.321, \mathrm{r}=$ 0.48 for faecal streptococci, $0.0742 \pm 0.881, r=0.96$ for coliforms and $0.351 \pm 0.675, \mathrm{r}=0.70$ for sulphite-reducing bacteria.

The total bacterial counts of the feeds are presented in Table 4 as broken down into different count ranges, and in Fig. 1 as the means of the logarithms during different production periods. The largest single group samples, $48.3 \%$, contained $10^{6} \ldots$ $6 \times 10^{6}$ bacteria per $\mathrm{g}$ of feed. The mean total bacterial count is fairly constant during the first four periods and is significantly elevated during the last production period. The elevation is significant at the 0.001 level. 
T a ble 4. Total bacterial count per g of ready-mixed mink feed, distribution of samples to different count ranges.

\begin{tabular}{lrc}
\hline $\begin{array}{l}\text { Count range } \\
\text { (per g) }\end{array}$ & Number of samples & \% of samples \\
\hline Less than $10^{6}$ & 39 & 16.7 \\
$10^{6} \ldots 6 \times 10^{6}$ & 113 & 48.3 \\
$6 \times 10^{6} \ldots 2 \times 10^{7}$ & 43 & 18.3 \\
$2 \times 10^{7} \ldots 10^{8}$ & 22 & 9.4 \\
More than $10^{8}$ & 17 & 7.3 \\
\hline Total & 234 & 100.0 \\
\hline
\end{tabular}

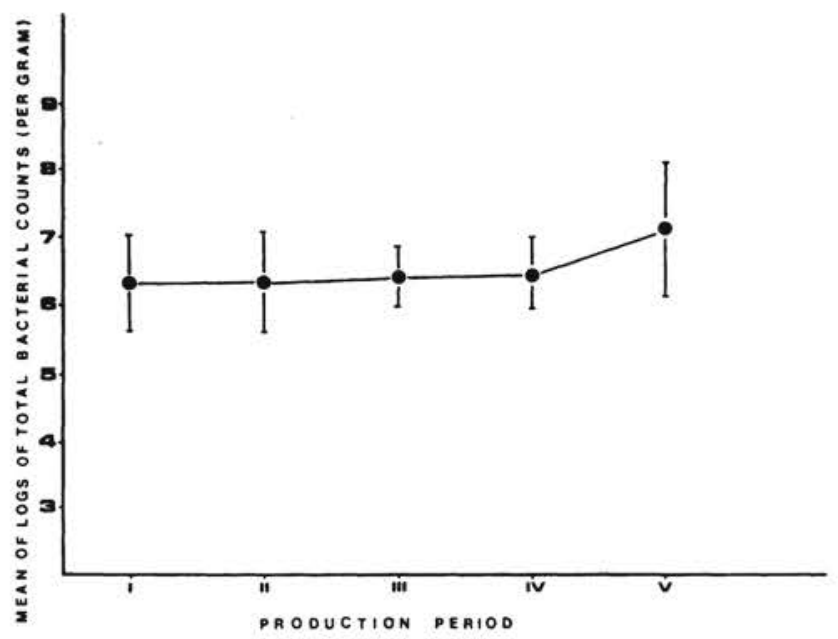

Figure 1. The means of the logarithms (mean $\pm s$ ) of the total bacterial counts of ready-mixed mink feed during different production periods. The production periods are the following; period I DecemberFebruary; period II March-April; period III May; period IV JuneAugust; period V September-November. The difference between the means of the logarithms of total bacterial counts of period $\mathrm{V}$ and period IV is significant $(\mathrm{P}<0.001, \mathrm{n}=136$, Student's t-test).

The results of the determinations of the number of the faecal streptococci, broken down into different count ranges, are presented in Table 5 and in Fig. 2 as the means of the logarithms during different production periods. The largest single group, $35.6 \%$, was in count range $2.5 \times 10^{4} \ldots 10^{5}$ bacteria per $\mathrm{g}$ of 
T a b l e 5. The number of faecal streptococci per $g$ of ready-mixed mink feed, distribution of samples to different count ranges.

\begin{tabular}{lcc}
\hline $\begin{array}{l}\text { Count range } \\
\text { (per } \mathrm{g})\end{array}$ & Number of samples & $\%$ of samples \\
\hline Less than $10^{3}$ & 27 & 11.6 \\
$10^{3} \ldots 5 \times 10^{3}$ & 25 & 10.7 \\
$5 \times 10^{3} \ldots 2.5 \times 10^{4}$ & 64 & 27.5 \\
$2.5 \times 10^{4} \ldots 10^{5}$ & 83 & 35.6 \\
More than $10^{5}$ & 34 & 14.6 \\
\hline Total & 233 & 100.0 \\
\hline
\end{tabular}

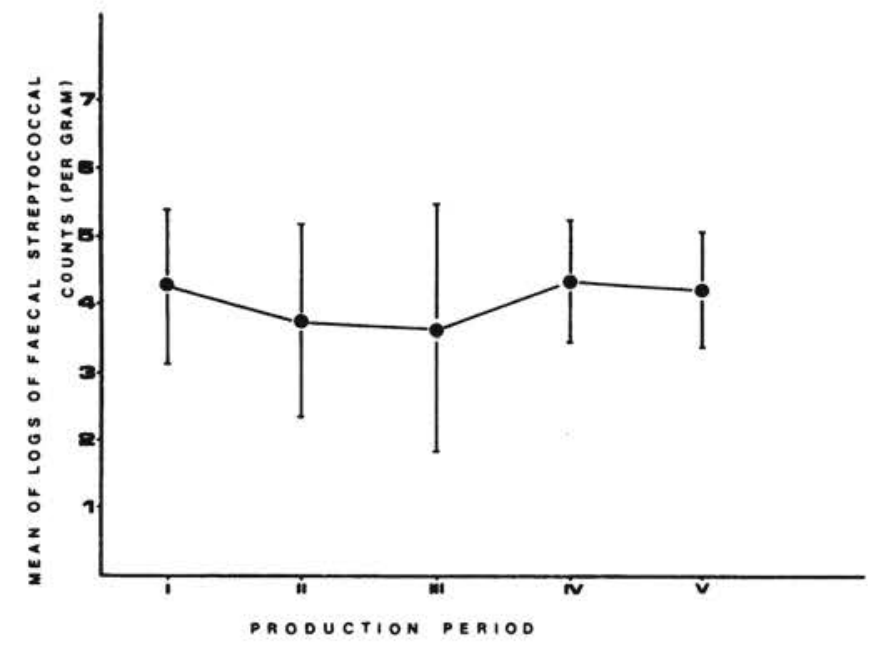

Figure 2. The means of the logarithms (mean $\pm s$ ) of the faecal streptococcal counts of ready-mixed mink feed during different production periods. For production periods, see legend of Fig. 1.

feed. The mean number of the faecal streptococci falls somewhat, though not significantly, during the second and third production period.

The results of the determinations of the number of the coliform bacterial counts, broken down into different count ranges, are presented in Table 6 and in Fig. 3 as the means of the logarithms during different production periods. Fifty $\%$ of the samples contained $5 \times 10^{3} \ldots 10^{5}$ coliform bacteria per $g$ of feed; 
Table 6 . The number of coliform bacteria per $g$ of ready-mixed mink feed, distribution of samples to different count ranges.

\begin{tabular}{lcc}
\hline $\begin{array}{l}\text { Count range } \\
\text { (per } \text { g) }\end{array}$ & Number of samples & \% of samples \\
\hline Less than $10^{3}$ & 54 & 23.1 \\
$10^{3} \ldots 5 \times 10^{3}$ & 33 & 14.1 \\
$5 \times 10^{3} \ldots 2.5 \times 10^{4}$ & 58 & 24.8 \\
$2.5 \times 10^{4} \ldots 10^{5}$ & 59 & 25.2 \\
More than $10^{5}$ & 30 & 12.8 \\
\hline Total & 234 & 100.0 \\
\hline
\end{tabular}

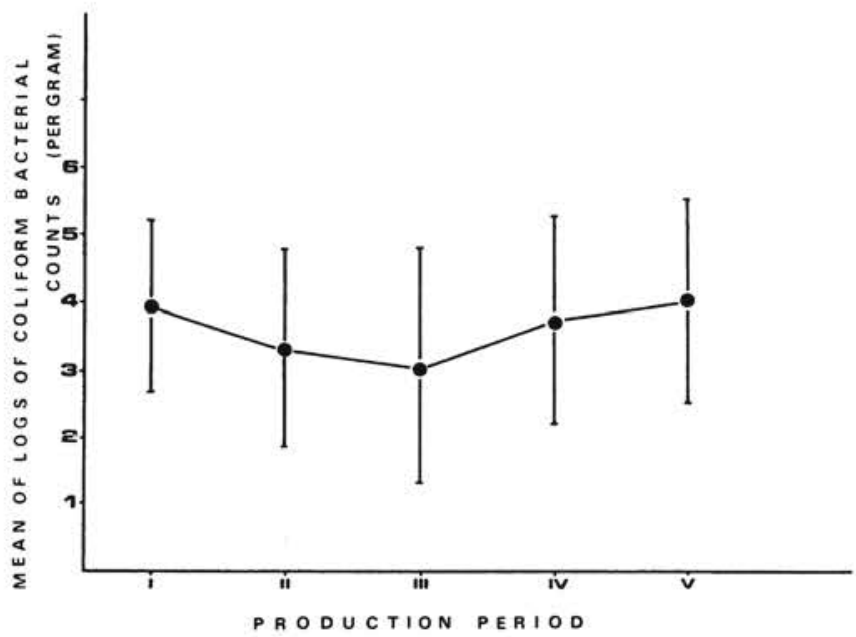

F ig ure 3. The means of the logarithms (mean $\pm \mathrm{s}$ ) of the coliform bacterial counts of ready-mixed mink feed during different production periods. The difference between the means of the logarithms during production periods I and IV is significant $(P<0.05, n=53)$. The difference between the means of logarithms of production periods $\mathrm{V}$ and III is significant $(\mathrm{P}<0.01, \mathrm{n}=85)$. See legend of Fig. 1.

$12.8 \%$ of the samples contained more than $10^{5}$ bacteria per $\mathrm{g}$; $62 \%$ of the samples contained less than $2.5 \times 10^{4}$ bacteria per $g$. Fig. 3 shows that a similar fall as was observed in the mean number of the faecal streptococci also occurs in the mean coliform counts during the second and the third periods. The decrease from the first to the third period is significant at the 0.05 
T a ble 7. The number of haemolytic bacteria per $g$ of ready-mixed mink feed, distribution of samples to different count ranges.

\begin{tabular}{lcc}
\hline $\begin{array}{l}\text { Count range } \\
\text { (per g) }\end{array}$ & Number of samples & \% of samples \\
\hline 0 & 11 & 4.6 \\
$0 \ldots 10^{3}$ & 24 & 10.0 \\
$10^{3} \ldots 5 \times 10^{3}$ & 41 & 17.0 \\
$5 \times 10^{3} \ldots 2.5 \times 10^{4}$ & 56 & 23.2 \\
$2.5 \times 10^{4} \ldots 10^{5}$ & 61 & 25.3 \\
$10^{5} \ldots 5 \times 10^{5}$ & 35 & 14.5 \\
More than $5 \times 10^{5}$ & 13 & 5.4 \\
\hline Total & 241 & 100.0 \\
\hline
\end{tabular}

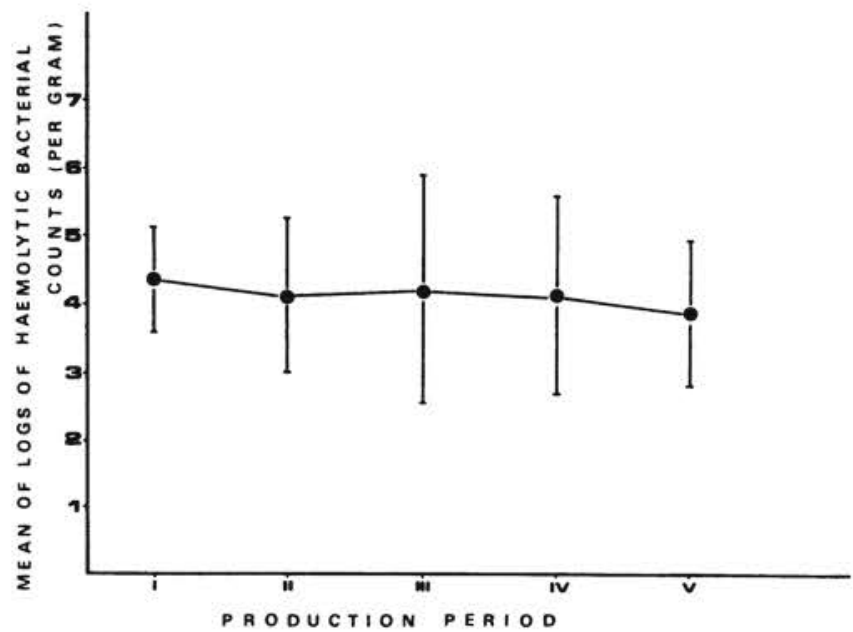

Figure 4. The means of the logarithms (mean $\pm s$ ) of the haemolytic bacterial counts of ready-mixed mink feed during different production periods. For production periods, see legend of Fig. 1.

level. The mean increase from the third period to the fifth period is significant at the 0.01 level.

The results of the determinations of the number of the haemolytic bacterial counts, broken down into different count ranges, are presented in Table 7 and in Fig. 4 as the means of the logarithms during different production periods; $48.5 \%$ of the samples contained $5 \times 10^{3} \ldots 10^{5}$ bacteria per $\mathrm{g} ; 5.4 \%$ of 
T a b le 8. The number of sulphite-reducing bacteria per g of readymixed mink feed, distribution of samples to different count ranges.

\begin{tabular}{lcr}
\hline $\begin{array}{l}\text { Count range } \\
\text { (per } \text { g) }\end{array}$ & Number of samples & \% of samples \\
\hline 0 & 40 & 17.2 \\
$0 \ldots 10^{3}$ & 32 & 13.8 \\
$10^{3} \ldots 5 \times 10^{3}$ & 23 & 9.9 \\
$5 \times 10^{3} \ldots 2.5 \times 10^{4}$ & 60 & 25.9 \\
$2.5 \times 10^{4} \ldots 10^{5}$ & 62 & 26.7 \\
More than $10^{5}$ & 15 & 6.5 \\
\hline Total & 232 & 100.0 \\
\hline
\end{tabular}

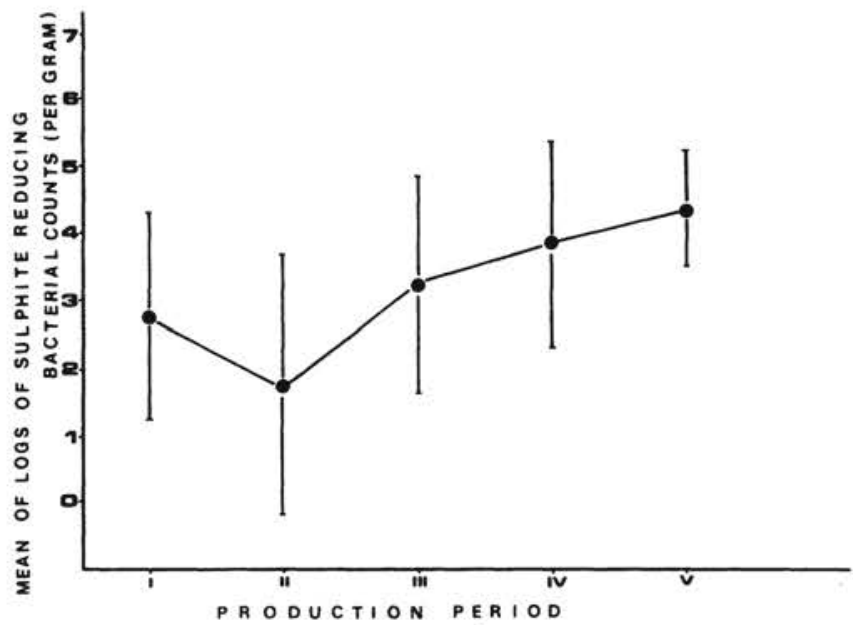

F i gure 5. The means of the logarithms (mean $\pm s$ ) of the sulphitereducing bacterial counts of ready-mixed mink feed during different production periods. The difference between the means of the logarithms during production periods I and II is significant $(\mathrm{P}<0.05$, $\mathrm{n}=71$ ), the differences between the means of the logarithms during production periods II and III, II and IV and II and V are significant $(\mathrm{P}<0.001, \mathrm{n}=87,118$ and 103 , respectively $)$.

the samples contained more than $5 \times 10^{5}$ bacteria per g; only $4.6 \%$ of the samples were negative with regard to haemolytic bacteria. Although differences between the samples are relatively high, the mean haemolytic bacteria content of ready-mixed mink feed is fairly constant throughout the different production periods. 
The results of the determinations of the number of the sulphite-reducing bacterial counts, broken down into different count ranges, are presented in Table 8 and in Fig. 5 as the means of the logarithms during different production periods; $17.2 \%$ of the samples were negative for sulphite-reducing bacteria, $52.6 \%$ contained $5 \times 10^{3} \ldots 10^{5}$ bacteria per $\mathrm{g}$, and $6.5 \%$ of the samples contained more than $10^{5}$ bacteria per g. The sulphite-reducing bacteria content is lowest during the second production period of the year and rises constantly until the pelting season. The increase from the second period to the third, fourth and fifth periods is significant at the 0.001 level.

\section{DISCUSSION}

The reproducibility of the results of the duplicate samples was good. The results are positively correlated to a sufficient extent so that the total procedure of the bacteriological analyses including sampling, can be considered to be well suited for the purpose (Fisher 1958).

Although apathogenic bacteria dominate the flora of the ready-mixed mink feed, pathogenic bacteria may also contaminate the feed through the raw materials (Gustavsen et al. 1969, Nordstoga \& Loftsgård 1969, Nordstoga 1970). The bacteriological quality control of the feed can provide information on the relative risk of the animals which eat the feed of being affected by feed-derived bacterial diseases (Loftsgård 1973, 1974, Poulsen \& Hansen 1975).

In Norway and Denmark the quality criterion for a good quality mink feed is a maximum of $6 \times 10^{6}$ bacteria per $g$ of feed (Loftsgård \& Yndestad 1973, Poulsen \& Hansen); in Denmark $84 \%$ of the 105 samples analysed contained less than this limit (Hansen 1973). In the Danish material the analyses were performed on unfrozen samples, and the plate count agar was incubated at $22^{\circ} \mathrm{C}$ for three days (Hansen). In Norway $75.8 \%$ of the samples analysed contained less than $6 \times 10^{6}$ bacteria per $\mathrm{g}$ of feed (Loftsgård \& Yndestad 1973). In the present material $65.0 \%$ of the samples contained less than $6 \times 10^{6}$ bacteria per $\mathrm{g}$ of feed. Although, because of the different determination techniques used, direct comparison between the three studies is not possible, it would seem that the total bacterial count of the Finnish feed is higher than that for Norway and Denmark. The significant elevation of the total bacterial counts during the last 
production period may be attributed to the use of lower quality raw materials during this period.

In the present study $49.8 \%$ of the samples contained less than $2.5 \times 10^{4}$ faecal streptococci per $g$ of feed. The corresponding figure in the Danish material was $82 \%$ (Hansen). Thus the Finnish mink feed is in this sense also of lower quality than the Danish feed.

In the Finnish material samples containing less than $2.5 \times$ $10^{4}$ coliform bacteria per $\mathrm{g}$ of feed were $62 \%$, the corresponding figures for Norway and Denmark were $84.2 \%$ and $80 \%$, respectively (Loftsgård \& Yndestad 1973, Hansen). Again it is obvious that the Finnish mink feed is of lower quality than the Norwegian and Danish feed. The reason for the lower coliform counts during the second and the third periods is obviously the better selection of raw materials during these periods.

The haemolytic bacteria in ready-mixed mink feed derive mostly from slaughter-house offal and consist usually of staphylococci and streptococci. In certain cases haemolytic Bacillus spp. have been found to derive from cereal and imported poultry offal (Juokslahti, unpublished). Only $4.6 \%$ of the samples were negative with regard to the haemolytic bacteria, Finnish mink feed is thus almost constantly contaminated with these bacteria.

The sulphite-reducing bacteria grown in high test tubes belong most often to the genus Clostridium (Skovgaard 1958). The most important species in this genus from the point of view of mink farming is $\mathrm{C}$. botulinum. The $\mathrm{C}$-toxin of $\mathrm{C}$. botulinum causes botulinum intoxication in minks. Almost $100 \%$ of minks in Finland are vaccinated yearly against C. botulinum type C intoxication. Although no species analyses of sulphite-reducing bacteria were performed in this study, the ready-mixed mink feed is so greatly contaminated with these bacteria that the annual botulism vaccination of minks is well indicated. This is also well confirmed by experience in practical mink farming (Juokslahti $1977 \mathrm{~b}$ ). The periodical changes in the sulphite-reducing bacterial counts are obviously due to the selection of the raw materials for feed production.

\section{ACKNOWLEDGEMENTS}

Thanks are due to Professor Timo Pekkanen, Head of the Department of Food Hygiene, College of Veterinary Medicine, Helsinki, for his guidance in bacteriological methodology and his help during all phases of this work. 


\section{REFERENCES}

Finnish Fur Breeders' Association. Statistics. Helsinki 1977.

Fisher, R. A.: Statistical methods for research workers. 13th Ed., Oliver and Boyd, Edinburgh 1958.

Gustavsen, S., S. Hauge, G. Loftsgård, T. Oftebro, L. Rosseb $\emptyset$, T. B. Tjaberg \& T. Aaneland: Repeated botulism outbreaks in mink caused by feed from a central processing plant. Canad. vet. J. $1969,10,244-247$.

Hansen, M.: Kort indlæg til færdigfoderets mikrobiologiske kvalitet. (Brief introduction to microbiological quality of ready-mixed mink feed). NJF subseksjonen for pelsdyr. Symposium om forkvalitet, Røros, September 27-29, 1972. Referatsamling 1973, 143-144.

Juokslahti, T.: Ajankohtaista. (Current events). Turkistalous 1977 a, $49,59-61$.

Juokslahti, T.: Rehulaboratorio kesäkuu 1977. (Feed laboratory June 1977). Turkistalous $1977 \mathrm{~b}, 49,350-352$.

Kangas, J.: Minkinrehujen kemiallinen koostumus ja minkkien ravinnekulutus. (Chemical composition of mink feeds and nutrient consumption of minks). Yrjö Helven Säätiö, Helsinki 1977. 107 pp.

Loftsgård, G.: Tre utbrudd av botulisme i höst. (Three cases of botulism during the autumn). Norsk Pelsdyrbl. 1973, 47, 447-448.

Loftsgård, G.: Forkvalitet og botulisme risiko. (Feed quality and botulism risk). Norsk Pelsdyrbl. 1974, 48, 170-172.

Loftsgård, G. \& M. Yndestad: Mikrobiologiske undersökelser av ferdigfor for mink. (Microbiological examinations of ready-mixed mink feed). Nord. Vet.-Med. 1970, 22, 595-598.

Loftsgård, G. \& M. Yndestad: Ferdigforets mikrobiologisk-hygieniske kvalitet og aktuelle konserveringsmidler. (Microbiological hygienic quality of ready-mixed feed and current preserving substances). NJF subseksjonen for pelsdyr. Symposium om forkvalitet, Røros, September 27-29, 1972. Referatsamling 1973, 134-142.

Mejerland, T.: Mikrobiella och kemiska analysdata på foder och fodermedel för mink. (Microbiological and chemical analysis data of feed and feed raw materials for mink). State vet. med. Inst., Stockholm 1975. 59 pp.

Mossell, D. A. A., A. S. De Bruin, H. M. J. van Diepen, C. M. A. Vendring $\&$ G. Zoutewelle: The enumeration of anaerobic bacteria, and of Clostridium species in particular, in foods. J. appl. Bact. 1956, 19, 142-154.

Nordstoga, K.: Forbårne infeksjoner hos pelsdyr. (Feed-borne infections in fur-bearing animals). Norsk Vet.-T. 1970, 82, 69-75.

Nordstoga, K. \& G. Loftsgård: Et utbrudd av smittsom abort - salmonellose - hos mink. (A case of contagious abortion - salmonellosis - in mink). Norsk Pelsdyrbl. 1969, 43, 425-426. 
Poulsen, H. \& M. Hansen: Bakterier og deres opf $\varnothing$ rsel i minkfoder. (Bacteria and their occurrence in mink feed). Dansk Pelsdyravl $1975,38,138-141$.

Skovgaard, N.: Om specifik tælling af clostridier i levnedsmidler. (Specific enumeration of Clostridium species in foods). 8th Nord. Vet.-möte, Proc., Helsingfors 1958, 766-772.

Slanetz, L. W. \& C. H. Bartley: Numbers of enterococci in water, sewage and feces determined by membrane filter technique with an improved medium. J. Bact. 1957, 74, 591-595.

\section{SAMMANFATTNING}

Minkfodrets bakteriologiska kvalitet $i$ Finland.

Djupfrysta prov av finskt minkfoder analyserades för totalantalet bakterier, antalet faekala streptokocker, antalet koliforma bakterier, antalet hemolyserande bakterier och antalet sulfitreducerande bakterier. Undersökningen omfattade 242 foderprov från 38 foderkök och större privata fodertillverkare vilkas årliga foderproduktion motsvarar $85 \%$ av hela landets fodertillverkning.

$48,3 \%$ av proven innehöll $10^{6} \ldots 6 \times 10^{6}$ bakterier per gram foder. Totalantalet bakterier var relativt konstant under de fyra första produktionsperioderna (december-augusti) och steg under den sista perioden (september-november). Den procentuella andelen prov innehållande mindre än $2,5 \times 10^{4}$ faekala streptokocker var $49,8 \%$. Den procentuella andelen prov som innehöll mindre än $2,5 \times 10^{4}$ koliforma bakterier var $62 \%$. Halten av koliforma bakterier var lägst under den tredje perioden (maj). 48,5\% av proven innehöll $5 \times 10^{3} \ldots 10^{5}$ hemolyserande bakterier per gram foder och 4,6\% var negativa. Halten av hemolyserande bakterier var relativt konstant under hela produktionsåret. $52,6 \%$ av proven innehöll $5 \times 10^{3} \ldots 10^{5}$ sulfitreducerande bakterier per gram foder och $17,2 \%$ var negativa. Halten av sulfitreducerande bakterier var som lägst under den andra produktionsperioden (mars-april).

Resultaten diskuteras och jämförs med motsvarande resultat från Norge och Danmark.

(Received May 8, 1978).

Reprints may be requested from: Tapio Juokslahti, Finnish Fur Breeders' Association, Feed Laboratory, Box 92, 65101 Vaasa 10, Finland. 